\title{
Struggles of Women to Access and Hold Landuse and Other Land Property Rights under the Customary Tenure System in Peri-Urban Communal Areas of Zimbabwe
}

\author{
Emaculate Ingwani
}

check for

updates

Citation: Ingwani, E. Struggles of Women to Access and Hold Landuse and Other Land Property Rights under the Customary Tenure System in Peri-Urban Communal Areas of Zimbabwe. Land 2021, 10, 649. https://doi.org/10.3390/ land10060649

Academic Editors: Walter T. de Vries and Pamela Durán Díaz

Received: 30 April 2021

Accepted: 10 June 2021

Published: 18 June 2021

Publisher's Note: MDPI stays neutral with regard to jurisdictional claims in published maps and institutional affiliations.

Copyright: (C) 2021 by the author. Licensee MDPI, Basel, Switzerland This article is an open access article distributed under the terms and conditions of the Creative Commons Attribution (CC BY) license (https:// creativecommons.org/licenses/by/ $4.0 /)$.
Department of Urban and Regional Planning, University of Venda, Thohoyandou 0950, South Africa; emaculate.ingwani@univen.ac.za; Tel.: +27-015-962-8536

\begin{abstract}
The struggles of women to access and hold landuse and other land property rights under the customary tenure system in peri-urban communal areas is increasingly becoming a cause for concern. These debates are revealed using a case study of a peri-urban communal area called Domboshava in Zimbabwe. Women living in this peri-urban communal area struggle to access and hold landuse and other land property rights registered under their names. The aim of this paper is to present an analysis of the struggles faced by women to access and hold landuse and other land property rights in Domboshava. This paper is a product of a literature review on land property rights, land tenure systems, and peri-urbanity more generally. Field data was intermittently collected in the peri-urban communal area of Domboshava over a period of four years from 2011 to 2014, as well as through post-research social visits stretching to 2019. Thirty-two women were conveniently selected and interviewed. I applied Anthony Giddens' structure-agency theory as a framework of analysis. The struggles to access and hold landuse and other land property rights by women are rooted in land transactions, social systems including the customary land tenure, patriarchy, as well as the peri-urban context of Domboshava. Responsible authorities on land administration in communal areas need to acknowledge the existence of new and invented ways of accessing and holding landuse and land property rights under the customary land tenure system, as well as to find ways to mobilize more opportunities for women on the peri-urban land market.
\end{abstract}

Keywords: customary land rights; peri-urban communal areas; women

\section{Introduction}

The struggles of women to access and hold landuse and other land property rights under the customary tenure system in peri-urban communal areas are increasingly becoming a cause for concern. These struggles expose explanations critical to understanding social differentiation processes that characterize relationships between women and land in peri-urban communities. These debates are revealed using a case study of a peri-urban communal area called Domboshava in Zimbabwe.

The peri-urban communal area of Domboshava is located about $15 \mathrm{~km}$ north-east of Harare, the capital city of Zimbabwe. Domboshava is regarded as a peri-urban communal area because of its location adjacent to Harare, and a mixity of land tenure regimes are applied to access and hold landuse and other land property rights. Conspicuous rural-urban linkages between Domboshava and Harare enable people to commute and straddle the divide daily. Domboshava presents a typical example of a dormitory village of Harare where spatial planning imperatives are never prioritized. The settlement pattern of Domboshava is characterized by modern housing structures surrounding rural service centers as development nodes that offer lower order goods and services.

While a profusion of scholarship on peri-urban areas exists [1,2], little investigation has been done to highlight the struggles faced by women to access and hold landuse and other land property rights in these areas. In the peri-urban communal area of Domboshava, 
women struggle to access and hold landuse and other land property rights registered under their names. Continual marginalization and misrepresentation of women's landuse and other land property rights is evident in Domboshava, and this was interrogated. Societies know who women are, but their landuse and other land property rights are never viewed as part of a larger universe of communal obligations.

The aim of this paper is to present an analysis of struggles faced by women to access and hold landuse and other land property rights in Domboshava. These struggles are contextualized as the difficulties or obstacles faced by women to access and hold landuse and other land property rights. The objectives of this paper are to: (1) explore the sources of women's struggles to access and hold landuse and other land property rights from selected experiences; (2) explain why women find it difficult to access and hold landuse and other land property rights in Domboshava; and (3) recommend policy proposals useful to ameliorate the plight of women from Domboshava, and those living under similar circumstances in the sub-Saharan African region.

This paper is an aggregate of six sections. After this brief introduction, the second section discusses the organization of land tenure systems, and landuse and land property rights in Zimbabwe. The third section details the methodology used. The fourth section brings to the fore the results drawn from the research findings. The fifth section provides a fine-grained discussion of the findings. The sixth section highlights the recommended policy proposals. Section seven concludes the paper.

\section{The Organization of Land Tenure Systems in Zimbabwe}

In Zimbabwe, land belongs to the state, and is broadly categorized and accordingly administered as communal (rural), urban, resettlement, large-scale commercial areas, and small-scale commercial areas. Within these broad categories of land types emerges a multiplicity of land uses, land users, and land tenure systems critical to the administration and distribution of landuse and other land property rights. Except for communal land, all the other types of land in Zimbabwe can be privately owned by individuals and institutions, have titles, and are tradable. Separate land laws and legal instruments exist, as well as land tenure systems that are used as reference points to administer landuse and other land property rights under these different categories of land types. Of interest to this paper is communal land, which is interchangeably referred to as rural land.

In Zimbabwe, communal land constitutes rural and resettlement areas. Land in communal areas has no title, and thus is non-tradeable. The traditional leaders constitutive of chiefs, headmen, and village heads are the custodians of communal landuse and other land property rights on behalf of the state. Land in communal or rural areas is administered under the communal land tenure system, which provides usufructuary property rights over the use of land. The communal land tenure system recognizes individual and collective landuse property rights and obligations on land held in common [3].

Within the communal land tenure system lies the customary land tenure system that sets the terms and conditions on how landuse and other land property rights can be acquired, held, and disposed according to local custom and tradition. Of interest to this paper is the application of the customary land tenure system to access and hold landuse property rights in a peri-urban context.

Land property rights are an important element of land tenure system which define the structures on accessing and holding of land and other land property rights by different people as individuals or collectives. Landuse property rights are socially and legally recognized entitlements used to control land parcels and other natural resources [4-6]. The concept of landuse property rights explains the entitlements "to access things or places, and thus, people belonging to certain places have every right to benefit from 'things' and the 'place' [6] (p. 13). As such, landuse property rights involve people's relationships with, and responsibilities on land including claims and disposal of such land [7]. In subSaharan Africa, landuse property rights are central to the wellbeing of individuals, and constitute a distinct category of people's socio-economic rights [8]. However, the dynamics 
of accessing and holding landuse and other land property rights by women in peri-urban areas are ambiguous and complex. It is therefore imperative to deliberate on the struggles entrenched in women actions to accessing and holding of landuse and other land property rights in a peri-urban communal area context.

\subsection{Land Property Rights in Peri-Urban Communal Areas of Zimbabwe}

Communal areas of Zimbabwe are rural, and are characterized by scattered villages where people depend on peasant farming for survival. Additionally, urban areas constitute commercial agglomerations referred to as towns and cities. Peri-urban areas are a buffer that separates the urban and rural fringes. As such, peri-urban areas are neither rural nor urban. Similar distinctions were observed in Ethiopian cities [2]. Of interest to this paper are the dynamics used to access and hold landuse and other land property rights in a peri-urban communal area experiencing transition from rural to urban due to incessant drivers of urbanization and migration.

Multiple landuse property rights exist for people living in peri-urban communal areas of Zimbabwe. The diverse landuse property rights are differentiated and categorized as residential, arable, grazing, and the commons [3]. Accessing and holding of these landuse property rights is enabled through land transactions. This paper presents an analysis of the struggles faced by women to access and hold landuse and other land property rights, mainly for arable and residential purposes. Holding of arable and residential landuse property rights determines access to other communal land property rights such as grazing and the commons including forests, mountains, wetlands, and rivers.

A dual regulatory framework constitutive of the communal and customary land tenure systems on one hand, and a plethora of statutory instruments on the other hand regulates the principles used to access and hold landuse and other land property rights in peri-urban communal areas of Zimbabwe. The statutory tools include the Regional Town and Country Planning Act Chapter 29:12 of 2001, Rural District Councils Act Chapter 29:13 of 2000, Urban Councils Act Chapter 29:15 of 2005, and the Communal Lands Act Chapter 20:04 of 2002. A combination of these codified laws, and the unwritten precepts of the customary land tenure system sets the guidelines on how to access and hold landuse and other land property rights in peri-urban communal areas of Zimbabwe.

The customary land tenure system is constitutive of principles that recognize individuals or collectives as carrying equal bundles of interests or landuse property rights to the same piece of land, while the state remains the ultimate owner of that land $[9,10]$. In addition, the system of customary land tenure provides localized guidelines on how landuse and other land property rights can be accessed and held through customs and traditions. The customary land tenure procedures are unwritten and are shaped by mere abstractions or representations derived from local institutions and community interests. Generational memories are useful in recognizing and distributing customary landuse and other communal land property rights in perpetuity.

In many sub-Saharan African countries such as Ghana, Tanzania, and Zimbabwe; the tenets of the customary land tenure system were institutionalized through colonial rule $[11,12]$. Contemporary principles that define customary land tenure systems in the greater part of sub-Saharan region seem to perpetuate the colonial agenda of directly and controlling the constitution of landuse and other land property rights of the marginalized and weaker elements of society such as women [12]. This is largely because the content of the different land tenure systems that can enable women to access landuse and other land property rights as primary holders in the region was never updated.

\subsection{Access, Use, and Holding of Land Rights by Women in Zimbabwe}

In Zimbabwe, the processes that define access and holding of landuse and other land property rights in communal areas by women are rooted in the socio-political dynamics of the customary land tenure system. Access and holding of landuse and other land property rights by women under the customary land tenure system is directly linked to 
men, who are the primary holders. Under the structure of the customary land tenure system, women are secondary holders of landuse and other land property rights because Zimbabwe is a patriarchal society. This arrangement alienates women, and reduces them to mere dependents. The disparities on access and holding of landuse and other land property rights between men and women are therefore institutionalized. Yet, contemporary provisions in the codified state land laws regard women and men as equals. This situation is not uncommon is sub-Saharan Africa where provisions in land laws recognize women's landuse and other land property rights on paper, and not in practice. For example, women of Savelugu in Ghana find it difficult to register landuse and other land property rights under their names, despite provisions in law [13]. Under these circumstances, land laws emerge as tools used to perpetuate segregation of women rather than to empower them [14].

Contestations to access and hold landuse and other land property rights under the customary land tenure system are therefore inevitable. Women's struggles to access and hold landuse and the allied land property rights are locally institutionalized in structures such as patriarchy, the customary land tenure system, and not necessarily statutory law. This paper therefore presents a nuanced analysis of the struggles faced by women to access and hold landuse and other land property rights in the peri-urban communal area of Domboshava in Zimbabwe where multiple land tenure systems are recognized and applied in response to the needs of different land seekers.

\section{Materials and Methods}

This paper is a product of a literature review on landuse property rights, land tenure systems, and peri-urbanity useful to understanding women's experiences in Domboshava [15]. Field data was intermittently collected in the peri-urban communal area of Domboshava from 2011 to 2014, as well as during post-research social visits stretching to 2019. The post-research social visits to Domboshava unraveled intriguing narratives on women's struggles to access and hold landuse and other land property rights in this peri-urban communal area. I felt it necessary to document selected experiences that can be used as reference points in future research. The experiences are however nonexhaustive. My personal experiences and positionality as a woman generated a fine-grained analysis of women's struggles related to access and holding of landuse and other land property rights in Domboshava.

\subsection{Data Collection Procedures}

A total of thirty-two women were conveniently selected and interviewed as part of a larger research sample during field data collection between 2011 and 2014. A sample of 32 interviews was reached when I felt saturated. In addition to these interviews, I engaged in countless informal conversations with women of Domboshava on different occasions until 2019 during my post-research social visits to the area. These informal conversations also prompted me to write this paper.

The women that participated in this research were ready and free to share their experiences where others felt insecure due to the sensitive nature of being involved in land transactions under the system of customary tenure in Domboshava. Nine of these women were widowed, two were divorced, and 21 were married. Of the widowed women, three were indigene and six were migrants. Of the divorced women, one was indigene and the other was a migrant. Of the married women, seventeen were migrant and the rest were indigene. Migrant widows dominated the study sample more than the other categories of women. This is because there are generally more migrants than indigenes living in Domboshava. Migrants perceive staying in Domboshava as arguably cheaper, and as an option that enables them to diversify their household livelihoods through straddling the rural-urban divide between the peri-urban communal area and Harare the capital city.

The 32 women I interviewed, and those conversed with later, stood in as heads of households, and in some cases as mere representatives of their members. The interviews and informal conversations highlighted the struggles of women to access and hold landuse 
and other land property rights in the peri-urban communal area. The findings presented in this paper are extracts from the narratives gathered from women from Domboshava. This paper thus documents specific and typical cases of the different experiences of women to access and hold landuse and other land property rights under a customary land tenure system in a patriarchal society.

\subsection{Data Analysis}

The analyses of women's experiences were packaged according to origin in terms of indigene and migrant categories; marital status as married, divorced, and widowed; as well as the nature of land transactions. These social differentiation constructs explain the assertiveness (of women) to access and hold landuse and other land property rights under a customary land tenure system that does not recognize equal treatment, and equality of women. The views from the narratives demonstrate capacity of women to represent opinions of their household members in a patriarchal decision-making context. In my analyses, I used pseudonyms to maintain anonymity of the women that participated in this research.

In order to come up with thick descriptions on struggles of women to access and hold landuse and other land property rights in the peri-urban communal area of Domboshava, I applied Anthony Giddens' structure-agency framework of analysis [16]. The structureagency theory was adopted to extract meaning from women's struggles to access and hold landuse and other land property rights within the system of customary tenure. The basic elements of Anthony Giddens' theory are the structure and agency [16]. An interplay of the structure and the agency leads to structuration - the duality of the structure [16]. Structures are the reference points that societies make use of to limit human action, and thus "tell us how to go about in social life" [16] (p. 42). Structures are set rules and procedures that guide individuals' actions in situated encounters [16]. On the other hand, agency is the intention and power of people (agents) to engage in certain activities and their capacity to do so [17].

In this paper, the system of customary land tenure is the structure that directs individual intention on how to access and hold landuse and other land property rights in the peri-urban zone. The structure is the set of rules that make up the system of customary land tenure. For example, the principles of the system of customary land tenure can limit or prevent women from accessing and holding landuse and other land property rights as primary holders, but through agency the intentions of women can be fulfilled. This is possible through following or even breaking rules that regulate and guide access and holding of landuse and other land property rights under the constitution of the customary land tenure system.

Notably, agency explains the ingenuity, ability, freedom of choice, and autonomy employed by women to access and hold landuse and other land property rights in a periurban context. Agency is the capability of women to interact with the structure to their advantage. Agency therefore constitutes individual women's intrinsic motives to contest set practices under the customary land tenure system, and to actualize their intentions. In this case, agency characterizes the complex patterns of women's conscious behavior to challenge what they perceive as structural barriers which prohibit or inhibit the attainment of individual goals such as setting up homesteads, obtaining arable land to practice peasant farming, and improved household wellbeing. For example, patriarchy does not allow women to access or to hold landuse and other land property rights under the customary land tenure system in rural areas, but through agency, women can buy or rent land under the same structure.

\section{Results}

The findings from the subsequent paragraphs were extracted from conversations with women from Domboshava, and remain appropriate representations or illustrations of what a lot of women experience to access and hold landuse and other land property rights in 
many peri-urban communal areas of Zimbabwe. Although the experiences of women from Domboshava are based on selected personal accounts, these remain useful representations of contestations on accessing and holding of landuse and other land property rights in peri-urban communal areas in most patriarchal settings of Zimbabwe, and the Sub-Saharan Africa region more generally.

\subsection{The Indigene-Migrant Distinctions}

Two broad categories of women were apparent in Domboshava, and these were differentiated as migrant and indigene. In this paper, indigene women of Domboshava are considered to come from 'legitimate' and original households with autochthonous landuse rights in the peri-urban communal area. These were referred to as 'daughters of the soil', while the males were the "sons of the soil" [1]. Whereas, migrant women and men were part of the outsiders, or 'strangers', or households that came from elsewhere during their lifetime to access and hold landuse and other land property rights in Domboshava [15]. Migrants settled in this peri-urban communal area on a permanent basis. Within the indigene-migrant distinction originates the social classification of women as married, divorced, widowed, or single. This classification of women is important because each of these categories presents diverse and deep-rooted struggles to access and hold landuse and other land property rights in the peri-urban communal area.

\subsection{An Emergent Customary Land Tenure System}

While Domboshava is neither rural nor urban, the rural features are more prominent than the urban ones because of the human settlement pattern, and the application of the customary land tenure system used to administer access and holding of landuse and other land property rights. Land in this peri-urban communal area is rural, and falls under the communal lands category. As such, the peri-urban communal area is in transition from rural to urban. This is visible through the presence of a coalescence of land uses, landuse activities, and land users [2]. The land users (including women) are simply inventing a 'new' customary land tenure system that condones land transactions otherwise forbidden under orthodox practices. The invented customary land tenure system enables access and holding of landuse and other land property rights with minimum or no obstacles. Such invented land tenure systems are often referred to as vernacular or clandestine land markets, or simply "new African land tenure systems" [1] (p. 897). Parallel application of invented land tenure system(s) and the orthodox customary land tenure system in Domboshava creates confusion that makes it difficult for women to register, and to secure their landuse rights and other land property rights.

\subsection{Sources of Women's Struggles}

The forms of struggles to access and hold landuse and other land property rights by women in Domboshava emerged as women interacted with the structure of the system of customary land tenure to their advantage; and are rooted in land transactions including inheritance, buying, renting, and grabbing. These struggles enabled women to (re)produce and alter the guidelines on accessing and holding landuse and other property rights under the system of customary land tenure. The struggles also empower women to liberate themselves in a patriarchal society. The findings demonstrate women's power to manipulate the system of customary land tenure to their advantage, with the aim to access and hold landuse and other land property rights.

The struggles of women in this case were rather contextually driven by the circumstances in response to personal needs, as well as the peri-urban nature of Domboshava. These findings could have been different if the sampled women were from urban or rural areas where the principles on accessing and holding landuse and other land property rights are guided by the structures, and not necessarily the changing local circumstances. All the 32 women thus engaged in different forms of land transactions to acquire and hold landuse 
and other land property rights for themselves, and on behalf of their household members. These land transactions include inheritance, buying, renting, and grabbing.

Inheritance under the system of customary land tenure is never monetized, and entails distribution of landuse and other land property rights to one's descendants. Under the customary land tenure system, inheritance of landuse and other land property rights is generationally passed in perpetuity based on memorized history. This is usually done after the death of the primary holder of land use rights. In some cases, distribution of landuse property rights through inheritance can be done to assist sons to establish new homesteads after marriage. However, the concept of inheritance has since transformed as the primary holders of landuse property rights preside over the inheritance process, as opposed to what happens after their death. The new approach to inheritance, particularly by widows, is a critical response to securing landuse rights against land grabbing. Indigene and migrant widows continuously alter inheritance procedures by disregarding their living status as property owners, and distribute part of their estates during their lifetime to avoid land disputes.

Buying involves exchanging land for money. In this regard, land is monetized for a negotiated value determined by the seller and the buyer. Meanwhile, renting though monetized, involves leasing of landuse and other land property rights for an agreed price and period, on contractual basis.

Land grabs are not a new phenomenon to accessing landuse and other land property rights globally. Land grabbing is not a result of mutual interaction, bargaining, or negotiation between landuse rights holders and others; but is characterized by 'snatching' people's land parcels without their consent. Land grabbing emerges as an important 'self-help' or 'self-allocation' mechanism for landuse and other land property rights.

\subsection{Representations of Women's Struggles}

The women's struggles to acquire and hold landuse and other land property rights under the customary land tenure system were prompted by their unique individual situations, statuses, and the need to provide for their household members. Individual agency of each of the women shows their ability to rationally make informed choices to access and hold landuse and other land property rights in Domboshava. Women of Domboshava thus engaged in the different land transactions to access and hold landuse and other land property rights in the peri-urban communal area. The subsequent paragraphs discuss selected cases that demonstrate the struggles of women to access and hold landuse and other land property rights through land transactions.

\subsubsection{Women's Struggles to Inherit Land}

In Domboshava, women can inherit landuse and other land property rights after the death of their husbands. However, such landuse and land property rights can be registered under the women's names on behalf of minor male children who can claim their rights when they reach 18 years of age. In most cases, such widows are vulnerable to land grabs largely because of the absence of a husband figure to protect the household land property rights against land grabbers. From the sampled women of Domboshava, both indigene and migrant widows are easy prey for land grabbers (mainly male kin) due to powerlessness to challenge patriarchal decisions. Women whose land is grabbed often struggle to get their land property rights back, and to ensure the wellbeing of the household members due to reduced plots for cultivation.

An example of land grabbing from Domboshava relates to an indigene woman who grabbed land from her kin. The owner of the land parcel was too sick to challenge the woman, and left the wife [Ida] to settle the dispute. In this case, Ida reported the case to the chief's council and openly challenged the land grabber, the chief's council, as well as men who supported the land grabber. Both women presented in this case were perceived by community members as 'more than feminine' because ordinarily women under patriarchy 
are expected to neither be capable of grabbing land nor to challenge decisions by the chief's council.

This case shows the ability of women's desire to 'own' landuse and land property rights. In contrast, the case shows the ability of women [Ida] to enforce resistance as a mechanism and tool to speak and act; it also shows their ability to contest undesirable situations that are oppressive despite their positions as secondary landuse and land property rights holders. The case of Ida also illustrates women's struggles against structures perceived as repressive.

This case shows that women are vulnerable, and disadvantaged by lack of voice in the decision-making processes, and hence fail to get justice in patriarchal systems. Clearly, there is lack of a legal support for women by various leaders from the local government or other social institutions. As such, women face struggles to defend their rights (including landuse rights) in such situations. Yet, through socialization women support and look after their husbands and the rest of the household members through performing gendered triple roles of production, reproduction, and community service.

Another case on women's struggles against land grabbing involved a migrant widow (Muneni). The land grab turned fatal as Muneni's husband was killed during a scuffle over 'ownership' of a piece of land. Instead of getting support from her in-laws, Muneni lost her matrimonial property to the young brother of her deceased husband. The case illustrates the extent to which individual agents can stretch their conscience to access and hold landuse and other land property rights. This case also demonstrates vulnerability of women to land grabs, as well as a lack of support from the community including kin. In Zimbabwe, widows look up to the local decision-making structures for justice. Due to widowhood, women like Muneni are rather weak and powerless to challenge the outcomes from a male dominated decision-making processes. Often, such widows fail to retain their households' landuse and other land property rights critical to sustaining the wellbeing of the members.

\subsubsection{Women's Struggles to Buy or Rent Land}

Women from both the indigene and migrant categories often acquire landuse and other land property rights through buying or renting. Girl children that are married to migrants lose their indigene secondary rights through marriage. In Zimbabwe, girl children use their indigene identities before marriage, and assume their husbands' indigene identities after marriage. As such, girl children are expected to gain secondary landuse and other land property rights through marriage.

As an example, Rose is an indigene woman who bought landuse rights in Domboshava when she got married to a migrant. As a girl child, she is not entitled to inherit landuse and other land property rights under the customary land tenure system. However, through marriage, she can acquire secondary landuse rights under her husband's name. Since her husband is a migrant, this means that Rose is a migrant by marriage. Under these circumstances, Rose used her indigene influence to buy landuse and other land property rights to establish a homestead for her household members. This case demonstrates unequal treatment of girl children with regards to accessing and holding of landuse and other land property rights within the customary land tenure system, compared to boys whose rights are perpetuated and secured through inheritance by the same structure.

Rose's case demonstrates that married women from indigene and migrant categories can obtain landuse and other land property rights in peri-urban areas through buying. Such women use their negotiating skills as a resource to access and hold landuse and other land property rights under the customary land tenure system where men are the primary rights holders. However, even when women buy the landuse rights and other land property rights on behalf of their households like the case of Rose, these are controlled by men (husbands) who have the prerogative to sanction further transactions on the land parcels if they so wish. Similarly, in Mwenezi District of Masvingo Province in Zimbabwe, women that 'obtained land' through the Fast-Track Land Reform Program had 'their land' registered 
under their husbands' names [18]. This situation does not only undermine landuse rights of married women, but also limits the extent to which feminine land property rights can stretch. These circumstances also present some form of subtle violence against women that is often perpetuated unchallenged.

Marriage thus remains a source of insecure landuse rights for women in peri-urban areas because of lack of land titles in their names [19,20]. For as long as women's landuse and other land property rights are registered under their husbands' or kins' names, there is a deliberate infringement of freedom to decide on how to use, and secure those land rights. This often includes the types of crops to be grown, or where to build a homestead. The situation also forbids women from sanctioning any form of land transactions on those land parcels except for the children's inheritance after the death of their father.

In another example, Edzai a migrant widow failed to inherit landuse and other land property rights on behalf of her children after the death of her husband. As a result, Edzai purchased land in Domboshava to establish a new homestead for herself and the children. In this case, buying landuse rights was an easier option than to contest the lost property rights. Similarly, some women from Masvingo Province in Zimbabwe were denied access to landuse and other land property rights after the deaths of their husbands [18]. Access to landuse and other land property rights by widows in patriarchal societies in most parts of the sub-Saharan Africa is commonly reserved for the male offspring, although legally females are entitled to such benefits [20]. Edzai's struggles demonstrates the significance of monetized land transactions as enablers to access and holding of landuse and other property rights in peri-urban areas.

Commodification of land in peri-urban zones empowers women to access landuse and other land property rights, and to control their own lives through participation, and involvement in a wider social universe characterized by changing gender relations [21]. These findings also show that accessing landuse and other land property rights through buying is driven by the women's need to secure the wellbeing of their household members. Clearly, women's struggles to access landuse and other land property rights in Domboshava emanate not only from the invented customary land tenure system, but also structural provisions of social systems that favor patriarchy.

\subsubsection{Struggles of Divorced Women through Buying and Renting Land Rights}

Women that choose to stay at their matrimonial homesteads after divorce assume the title of head of household for their children. Such women do not look up to their husbands for any form of household support. This means that women who choose to remain at their husbands' homesteads after divorce alienate themselves and their children from the father figure as the household head. In some cases, divorced women relinquish their secondary landuse and other land property rights, leave their matrimonial homesteads (including children), and return to their maternal roots. Divorced indigene women advanced in age usually choose to stay at their matrimonial homesteads under their divorced husbands' household headship 'for the sake of their children'. This demonstrates resilience in women's struggle to access and securely hold landuse and other land property rights for their household members by 'staying put'.

\section{Discussion}

The narratives presented in this paper were gathered from conversations with women from the peri-urban communal area of Domboshava. As such, the findings explain how women altered the principles that govern access and holding of landuse and other land property rights under the system of customary land tenure to their advantage. This is because Domboshava is neither rural nor urban, but a compound of both. If these women were from a typical urban area of Zimbabwe, the dynamics of accessing landuse and holding other land property rights were going to be formal and less contingent. Land transactions on urban markets are guided by written procedures because such land is legally deemed tradable, and is titled. 
On the other hand, if these women were from a typical rural area, their behavior was going to be somewhat different. In most rural areas of Zimbabwe, women do not buy landuse rights. There is absence of landlessness in rural areas. Due to abundance of land in rural areas, there is no land 'rush', as with the case in peri-urban areas such as Domboshava.

What is happening in Domboshava is a result of porous guidelines on accessing and holding of landuse and other land property rights under the customary land tenure system in a peri-urban context. Access and holding of landuse and other land property rights depends on the local and contextual interpretation of custom and tradition procedures that were accepted, recognized, and understood in their many variations by all stakeholders including community residents and traditional authorities. The guidelines are unwritten and ad hoc concomitant with what happens on peri-urban land markets. Understanding the findings from the perspective of Domboshava unraveled salient and often undocumented truths shrouding women's struggles to access and hold landuse and other land property rights. This is only possible in a typical peri-urban zone where vernacular land markets are prevalent. Women of Domboshava simply took advantage of the invention, local interpretation, and application of the customary land tenure system procedures in a periurban communal context to access and hold land rights and other land property rights under their names.

\subsection{A Gendered Perspective to the Struggles}

In terms of gender, women are not a homogenous group, and have diverse land needs. The research findings show that women within their life cycles as daughters, married women, mothers, divorcees, or widows present differential outcomes from their experiences on accessing and holding of landuse and other land property rights under the customary land tenure system in a peri-urban communal area. Women buy, rent, and inherit landuse and other land property rights under different circumstances in peri-urban communal areas. Women from both the indigene and migrant categories are generally excluded from holding primary landuse rights under the customary land tenure system, and thus resort to land transactions. This demonstrates women's capabilities to access and hold landuse rights, as well as to push for the recognition of these land rights through local structures largely dominated by men. In this regard, women can access and hold landuse and other property rights - a shift from the traditional prerogative reserved for males in a patriarchal community. While women are constrained by patriarchy to obtain land, in Domboshava, patriarchy as part of the social system is not wholly deterministic to access and hold landuse and other land property rights as women employ agency to go beyond this social structure to fulfil their goals [18].

Therefore, it is not only disparities embedded in gender that are significant variables in explaining differential outcomes from women's struggles to access and hold landuse and other property rights under the customary land tenure system, but also how this social system is applied and understood in a peri-urban environment. Experiences from Domboshava demonstrate that women share common responses to oppression through dynamic and contextualized action largely determined by the structure of customary land tenure system, and the peri-urban nature of the community they live in.

\subsection{Women's Status, and Access to Landuse and Other Land Property Rights}

In Domboshava like in most rural communities of Zimbabwe, divorced women retain the role of an economic provider for their children or household members, but not on any matters of decision-making concerning their husbands' property such as land. Through divorce, women obtain freedom and autonomy to purchase landuse and other land property rights under their names, for as long as they remain unmarried. The findings show that divorced women from both the indigene and migrant categories are determined to obtain landuse and other land property rights by using their purchasing, negotiating, and bargaining powers. However, the assumption of household headship by female widows 
and divorcees from both indigene and migrant categories is temporary, and only remains valid until they get married.

Poor divorced women without constant income streams are likely to jeopardize the wellbeing of their household members because landuse property rights in peri-urban communal areas such as Domboshava are a fee good obtainable on a vernacular land market. For example, Alice a divorced migrant woman, failed to purchase a piece of land due to limited income. This means that poor women are likely to remain 'landless' despite the existing opportunities to acquire landuse and other land property rights. Such trends were observed in Mtoko communal area in Zimbabwe where "widows with little or no wage labour were the poorest" [22] (p. 4). Thus, the ability of women to mobilize enough finances to purchase landuse and other land property rights in a patriarchal system is often not only determined by women's individual potential, but other macro-economic factors such as affordability.

Purchasing land in Domboshava provides the structural relevance of market-oriented landuse and land property rights to divorced women who find it difficult to return to their natal homes for fear of reprisal and disgrace. This means that access and holding of landuse and other land property rights by women in their divorced/married/widowed/single categories depends on individual capabilities to mobilize finance, and to negotiate land transactions within a patriarchal system. Thus, positive outcomes from these struggles to access landuse rights and other land property rights in peri-urban communal areas are not solely dependent on the structure of the customary land tenure system, but the individual women's capacities in believing in themselves.

\subsection{Role of Purchasing Power in the Struggles}

The different options of monetized land transactions in Domboshava enable women to access and hold primary landuse and other land property rights, and exercise their freedom and authority in decision-making over land parcels on behalf of their household members. Sadly, there are no distinct arrangements that can assist poor women who lack purchasing power to obtain landuse and other land property rights in the peri-urban communal area. Raising income in a dollarized economy is difficult for women of Domboshava because of low-income levels, unemployment, and hyperinflation experienced in the country.

From a sample of the 32 women interviewed, none of them had a formal job. Most women relied on inconstant income streams from meager earnings obtained through piece jobs, petty trading of small goods, and sale of vegetables on the informal markets in Domboshava and Harare. This means that women's abilities to mobilize finance and to negotiate deals determine access and holding of landuse and other land property rights under patriarchy, and not necessarily the structure of the customary land tenure system. Since women are prohibited to make decisions concerning access and holding of landuse and land property rights in a male dominated society, patriarchy as a social system sustains and drives these struggles. Simultaneously, the struggles sustain patriarchy.

\section{Recommended Policy Proposals}

The tenets of customary land tenure systems in Domboshava are increasingly evolving as women continue to access and hold landuse and other land property rights through different land transactions. What is happening in Domboshava and other peri-urban communal areas elsewhere in Zimbabwe, as well as some parts of sub-Saharan Africa, remains important in shaping the present and future configuration of landuse rights under the system of customary land tenure. There is therefore a need for a deep introspection into ways of adopting policy recommendations that can recognize access and holding of landuse and other land property rights by women through turning the struggles and contestations into opportunities. Policy recommendations from literature on best practices from Ghana [13], and Ethiopia [2] can be useful in (re)shaping guidelines on accessing and holding of landuse and other land property rights in peri-urban communal areas. However, contextualized policy options remain important. I therefore make the following recommendations: 
(1) The responsible authorities on land administration in communal areas need to acknowledge the existence of new and invented ways of accessing and holding landuse and other land property rights under the customary land tenure system in areas that are situated in the urban periphery. This means admitting that the 'old' ways of accessing land are increasingly getting obsolete. There is need for embracing responsive structural changes within the system of customary land tenure in peri-urban communal areas. Communal land administrators must make concerted efforts to study how the decisions on distributing land rights are made by the traditional leaders in peri-urban communal areas.

(2) Constant updates and revision of state land laws and land policies on communal and customary land tenure systems are a prerequisite to enable guidelines on accessing and holding of landuse and other land property rights to remain relevant in contexts experiencing ubiquitous change such as the peri-urban areas.

(3) A revision on land administration laws and policies in communal areas needs to make provisions that allow women to access, hold, and register landuse and other land property rights under their names without interference from their kin and husbands. This increases security of tenure, and reduces women's vulnerability against principles of orthodox custom, tradition, and patriarchy that reserve the prerogative of primary landuse holding titles solely for males. This proposal however requires intensified community education on why responsive customary land tenure systems are necessary, and how women can proceed to register their land titles through the local authorities. This can be done through holding community workshops and dialoguing with all stakeholders in the land administration structures such as the government departments, the district councils, traditional leaders, and women's forums.

(4) Empowerment of women that live in peri-urban areas through mobilization of their capacities, voices, and finances, as well as opportunities on the land market remains critical. This can be done by availing finances through established lending institutions to allow women to borrow money at negotiated interest rates to buy, rent, and register landuse and other land property rights under their names. Clubs are potential platforms for pooling together capacities and financial resources to enable women to fully participate on the peri-urban land markets.

\section{Conclusions}

Land transactions between indigenes, between migrants, as well as between indigenes and migrants are common in Domboshava. Accessing and holding of landuse and other land property rights within the customary land tenure system by secondary holders such as women was given an in-depth analysis. In their narratives the women's responses demonstrate non-opinionated individual responses, as well as strong gendered relationships reproduced from the collective landuse rights under the system of customary land tenure.

Women living in peri-urban communal areas lack secure landuse and land property rights, yet they bear the huge task of ensuring the wellbeing of their household members. Despite their powerlessness under patriarchy, these women go beyond what they perceive as structural barriers to access landuse and other land property rights under the system of customary land tenure. This shows that women are active agents in the production and reproduction of structures on landuse rights as they contest access to, and holding of such property rights in peri-urban locales. The struggles are often limited not by patriarchy, gender, or status of women as married, widowed, divorced, or single; but rather by purchasing power to buy and hold landuse and other land property rights on the vernacular land market.

This paper therefore strongly recommends a thorough revision of the current structure of the customary land tenure system to allow women equal access to, and holding of landuse rights and other land property rights as their kith and kin. This can be possible through a provision of a more responsive and creatively configured land administra- 
tion laws and policies that can avail more choices within the invented customary land tenure system.

A reflection on the constitution of the customary land tenure system in Zimbabwe, and some parts of sub-Saharan Africa more generally is greatly needed to ease women's struggles to access and hold landuse and other land property rights in peri-urban communal areas. Future research directions must therefore highlight an emergent customary land tenure model that is responsive not only to women's land needs, but also to residents of peri-urban communal areas in their diversity.

\section{Patents}

There are no patents resulting from the work reported in this manuscript.

Funding: The publication fees were covered by the Chair of Land Management of the Technical University of Munich, Germany.

Institutional Review Board Statement: The ethical review and approval were waived for this study, because the paper is an output of my $\mathrm{PhD}$ thesis which was granted ethical clearance at Stellenbosch University.

Informed Consent Statement: Informed consent was obtained from all the subjects involved in this study. Women that participated in this research did so voluntarily.

Data Availability Statement: Not applicable.

Acknowledgments: I would like to thank the Chair of the Land Management of the Technical University of Munich, Germany for covering the publication fees for this paper. The paper is part of my $\mathrm{PhD}$ research at Stellenbosch University.

Conflicts of Interest: The author declares no conflict of interest.

\section{References}

1. Chimhowu, A. The 'new' African customary land tenure. Characteristics, features and policy implications. Land Use Policy 2018, 81, 897-903. [CrossRef]

2. Wubie, A.M.; de Vries, W.T.; Alemie, B.K. Synthesizing the dilemmas and prospects for a peri-urban land use management framework: Evidence from Ethiopia. Land Use Policy 2021, 100, 105122. [CrossRef]

3. Cousins, B. Characterising "communal tenure": Nested systems and flexible boundaries. In Land, Power and Custom: Controverses Generated by South Africa's Communal Land Rights Act; Claassens, A., Cousins, B., Eds.; UCT Press: Cape Town, South Africa, 2008; pp. 109-137.

4. Tacoli, C. Understanding the Opportunities and Constraints for Low-Income Groups in the Peri-Urban Interface: The Contribution of Livelihood Frameworks. Peri-Urban Research Team; Development Planning Unit: London, UK, 1999.

5. Quan, J. Land tenure, economic growth and poverty in sub-Saharan Africa. In Evolving Land Rights, Policy and Tenure in Africa; Toulmin, C., Quan, J., Eds.; IIED Bookshop: London, UK, 2000; pp. 31-50.

6. Peters, P.E. The erosion of commons and the emergence of property: Problems for social analysis. In Proceedings of the Society for Economic Anthropology, Notre Dame, IN, USA, 10-12 March 1994.

7. Simbizi, M.C.D.; Bennette, R.M.; Zevenbergen, J. Land tenure security: Revisiting and refining the concept for sub-Saharan Africa's rural poor. Land Use Policy 2014, 36, 231-238. [CrossRef]

8. Walker, C. Elusive equality: Women, property rights and land reform in South Africa. S. Afr. J. Hum. Rights 2009, 25, 467-490.

9. Tsikata, D.; Whitehead, A. Policy discourses on women's land rights in sub-Saharan Africa: The implications of the return to customary. J. Agrar. Chang. 2003, 13, 67-112.

10. McAuslan, P. Only the name of the country changes: The diaspora of "European" land law in Commonwealth Africa. In Evolving Land Rights, Policy and Tenure in Africa; Toulmin, C., Quan, L., Eds.; IIED Bookshop: London, UK, 2000; pp. 75-96.

11. Cousins, B. Property rights and power in Zimbabwe's communal lands: Implications for agrarian reform in the 1990s. In Proceedings of the Conference on Land Policy in Zimbabwe After "Lancaster", University of Zimbabwe, Harare, Zimbabwe, 13-15 February 1990.

12. Mamdani, M. Citizen and Subject, Contemporary Africa and the Legacy of Late Colonialism; Fountain Publishers: Kampala, Uganda, 1996.

13. Ameyaw, P.P.; Chigbu, U.E.; De Vries, W.T.; Mwesigye, S.P.; Yeboah, E. Women and customary land tenure: Emerging developments and ways forward in Savelugu, Ghana. In Proceedings of the World Bank Conference on Land and Poverty, Washington, DC, USA, 25-29 March 2019. 
14. Duran-Diraz, P.; Armenta-Ramirez, A.; Kurjenoja, A.K.; Schumacher, M. Community development through the empowerment of indigenous women in Cuetzalan Progresso, Mexico. Land 2020, 9, 138-163.

15. Hungwe, E. Land Transactions and Rural Development Policy in the Peri-Urban Communal Area of Domboshava, Zimbabwe. Ph.D. Thesis, Stellenbosch University, Stellenbosch, South Africa, 2014. Available online: http:/ / scholar.sun.ac.za (accessed on 29 April 2021).

16. Giddens, A. The Constitution of Society. Outline of the Theory of Structuration; Polity Press: Cambridge, UK, 1984.

17. Stones, R. Structuration Theory; Palgrave: New York, NY, USA, 2005.

18. Mutopo, P. Women's Struggles to Access and Control Land and Livelihoods After Fast Track Land Reform in Mwenezi District, Zimbabwe. J. Peasant Stud. 2011, 38, 1021-1046. [CrossRef]

19. Nyamu-Musembi, C. Breathing Life into Dead Theories About Property Rights: De Soto and Land Relations in Rural Africa; IDS Working Paper 272; IDS: Brighton, UK, 2006.

20. Makura-Paradza, G.G. Single Women, Land and Livelihood Vulnerability in a Communal Area in Zimbabwe; Wageningen Academic Publishers: Wageningen, The Netherlands, 2010.

21. Cliffe, L.; Alexander, J.; Cousins, B.; Gaidzanwa, R. An overview of the Fast-Track Land Reform in Zimbabwe. Editorial Introduction. J. Peasant Stud. 2011, 38, 907-938. [CrossRef]

22. Matondi, P.B.; Dekker, M. Land Rights and Tenure Security in Zimbabwe's Post Fast Track Land Reform Programme. A Synthesis Report for LandAc; Ruzivo Trust: Harare, Zimbabwe, 2011. 